The BDJ News section accepts items that include general news, latest research and diary events that interest our readers. Press releases or articles may be edited, and should include a colour photograph if possible. Please direct your correspondence to the News Editor, Kate Craig at the BDJ, 64 Wimpole Street WIG 8YS or by e-mail to bdj@bda-dentistry.org.uk

\section{Laser first at GKT}

Undergraduates at Guys, Kings and St. Thomas's (GKT) Dental Institute are soon to be introduced to the use of lasers in dentistry. It is thought to be the first time that undergraduates will receive tuition in this subject.

In the very near future students, in the department of Team Care Dentistry, in years 4 and 5 will be invited to put their names down for clinical demonstration classes during which they can observe laser treatment being carried out on patients.

These clinical classes will be led by Dr Chris Louca, lecturer in Clinical Dentistry. The sessions will also eventually be open to Professionals Complementary to Dentistry (PCDs) who work with Year 4 and 5 undergraduates as part of the pioneering Team Care Dentistry concept.

The degree to which lasers will become part of the curriculum at GKT is still unclear. Firstly, they are still relatively new and expensive items of equipment. In addition there are still several areas that need to be more thoroughly investigated through basic research and clinical trials. Dr Louca said that he would want the clinical classes to feature patients receiving a broad spectrum of treatment. This would include the removal of caries and general soft tissue management required prior to restorative procedures. In addition endodontic and periodontic techniques will be demonstrated. At the moment Team Care Dentistry at GKT has access to both hard tissue (Er:YAG) and soft tissue (CO2 and Diode) lasers.

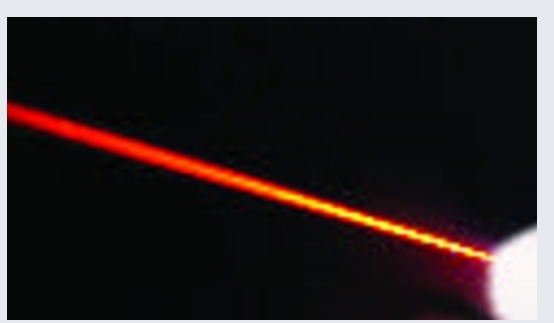

\title{
DDU teacher of the year
}

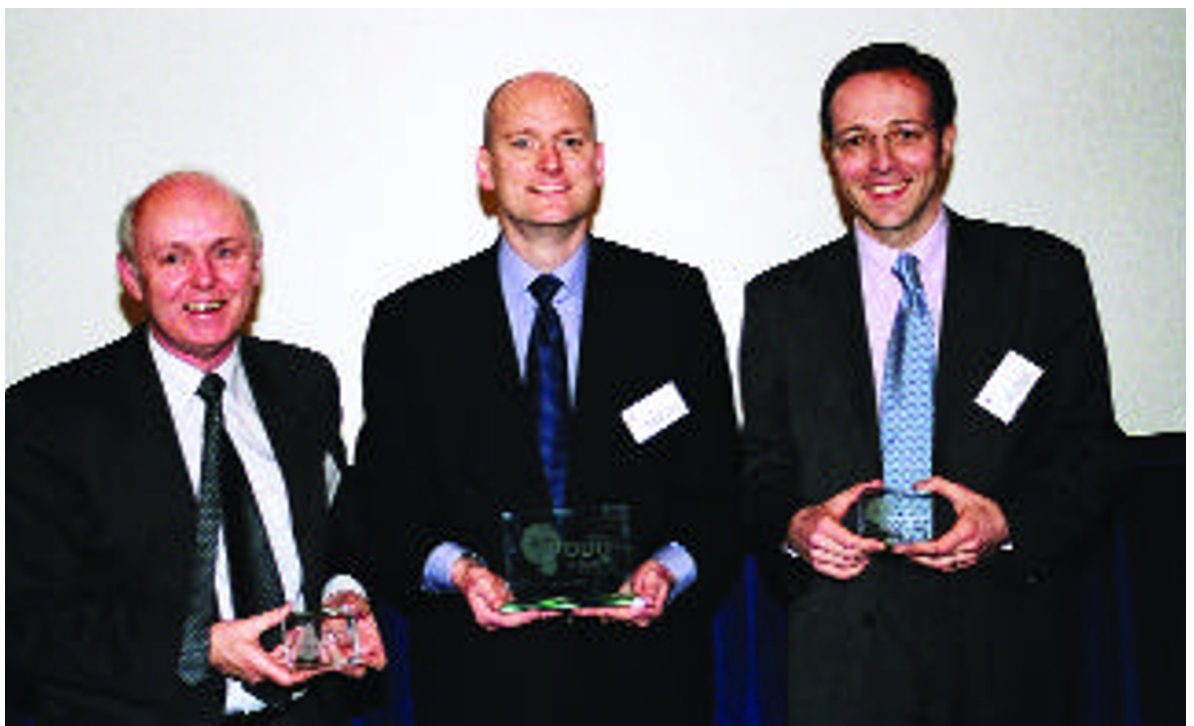

Dr Jeremy Hayes from the University of Wales College of Medicine has been named 2001/02 DDU Dental Teacher of the Year for his outstanding work as a dental teacher.

Dr Hayes demonstrated to the judges a commitment to his students and innovation in teaching. In the teaching project he presented at the awards, he explained how he identified a gap in some students' knowledge, namely that they had not learnt how to use X-ray film holders correctly during endodontics, and so were producing poor quality radiographs. He immediately set about addressing this knowledge gap, involving his students in the process, and monitored its on-going effectiveness.

Dr Hayes (above, centre) was selected from a short-list of three dental teachers from all over the UK and Ireland - the two other finalists were Dr Mark Ide (above, right) from GKT Dental Institute, London and Dr Gerry Cowan (above, left) from the Queen's University of Belfast School of Clinical Dentistry. The winner was selected after each of the finalists gave a short presentation to almost 100 people at the awards ceremony on Wednesday 19 March 2003 held at the Barber-Surgeons' Hall in London. Each of the finalists received an award, certificate and $€ 250$. The winner's dental school, the University of Wales College of Medicine, also received a donation of $£ 500$ towards the cost of educational material.

\section{Management qualification for dentists}

A new business management qualification for dentists and senior business managers in dental practice was launched at this year's BDA Conference.

The Executive Diploma in Management launched by UMD Professional Ltd is awarded by the Institute of Leadership and Management and has been designed to provide participants with the practical business skills required to run a dental practice. The diploma is the equivalent of a level $5 \mathrm{NVQ}$, which is considered to be the same as a postgraduate qualification. Completion of the diploma provides eligibility for membership of the Institute (MInstILM).

The Diploma focuses on business management and strategy rather than the administrative aspects of dental practice. Areas the qualification covers include planning and resource management, organisational communication, financial management and human resource management. Assessment is continuous, involving assignments and a major consultancy project carried out within the practice, making it as relevant to business management in practice as possible. 


\section{DIARY}

June 2003

SAAD 10th International Dental Congress on

Modern Pain Control

Date: 05.06.03-07.06.03Venue: Edinburgh International Conference Centre, Scotland

Contact: Congress Secretariat

Tel: +44 (0)1413310123

Fax: +44 (0)1413310234

E-mail: info@saaduk.org

\section{September 2003}

Annual Meeting of the International Society for the Prevention of Tobacco Induced Diseases

Date: 29.09.03-01.10.03

Venue: Winnipeg, Canada

Contact: PTID-Society (Congress 2003)

Fax: +1 (204) 789-3913

E-mail: PTIDSociety@AOL.COM

\section{October 2003}

9th Biennial Congress of the International

Academy of Periodontology

Date: 24.10.03-27.10.03

Venue: Cape Town International

Conference Centre

Tel: +27219389245

Fax: +27219332649

www.sun.ac.za/iap2003

\section{May 2004}

BDA National Annual Conference

Date: 06.05.04-08.05.04

Venue: Bournemouth International Centre

Contact: Events Office,

British Dental Association

Tel: +44 (0) 2075634590

Fax: +44 (0) 2075634591

E-mail: events@bda.org

\section{Marathon effort raises funds for hospice}

Edward Moncrief, principal of the 2TH Dental Practice in Market Harborough, raised £2500 for LOROS, the Leicestershire and Rudland Hospice, by completing the London Marathon on Sunday 13 April.

Edward finished the race in 4 hours 23 minutes. 'The crowd were fantastic and kept me going, especially in the last few miles,' he said.

Edward would like to thank all the team at the practice for their support and everyone who sponsored him.

Edward Moncrief at the start of the London Marathon on Greenwich Park.

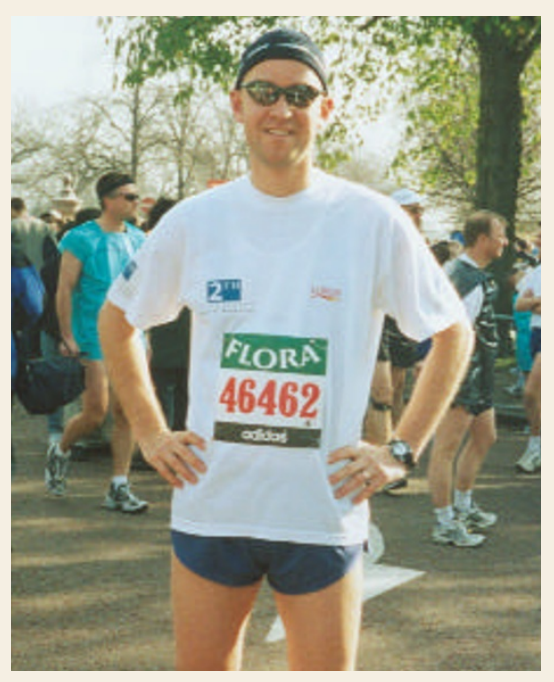

\section{Bill paves the way for NHS shake-up}

The Health and Social Care (Community Health and Standards) Bill published on 13 March paves the way for the biggest shake-up in NHS dentistry for over half a century.

At the heart of the legislation is a new responsibility for Primary Care Trusts (PCTs) in England and Local Health Boards in Wales to provide dental care for people in their areas.

The duty of provision of dental care will enable the PCT to contract with providers using a similar system of remuneration to the current GDS or PDS system, a capitation system or a salaried service. For the first time it will be decided locally rather than by central government.
The bill is timetabled to become law around November 2003, however the end of its parliamentary process does not mean immediate implementation. It will be enabling legislation that allows the Secretary of State in England or the National Assembly of Wales to implement different parts at different times. The target for implementing the dental part of it is April 2005 in England.

Responding to the Bill's publication, John Renshaw, Chair of the Executive Board of the British Dental Association, said:

"The Bill represents a once in a generation opportunity to save NHS dentistry after decades of neglect by successive governments." 


\section{New committees set up by GDC}

The GDC has set up the following committees and groups following the first formal meeting of the new, smaller, 29member Council on 10 April 2003.

\section{Governance Working Group}

The Governance Working Group will comprise the newly-elected President, Hew Mathewson, and five other members elected by the Council, including at least one member from each of the three categories - dentist, PCD and lay; the Chief Executive and one of the Chief Dental Officers would serve as advisers to the Group; the President would chair the Group.

The Council agreed the following remit for the Group:

To develop a detailed set of options for discussion by the full Council, covering the following issues:

1. An analysis of the main functions and responsibilities of the membership

2. Structures and processes for the discharge by the membership for each of those functions

3. Leadership within the membership, including the role of the President and possibly Vice and/or Deputy President(s)

4. The relationship between the membership, the staff and others discharging the Council's functions

5. Modes of involvement of key nonmember stakeholders

6. Accountability of the membership to those to whom it is accountable

7. Accountability of individual members in respect of their behaviour.

The group is asked to present options and offer analysis of their advantages and disadvantages; not to identify favoured solutions in the form of recommendations.
Holding Finance Committee

The council set up a holding Finance Committee, agreeing that it should comprise the President, plus six members elected by the Council, including at least one member from each of the three categories - dentist, PCD and lay.

The Council agreed the following remit for the committee:

a) To take steps as necessary to prepare information and recommendations for the next meeting of Council in relation to the setting of registration fees for 2004

b)To take such action as is required in advance of the Council's second meeting to ensure the continuing financial viability and financial probity of the Council

c) To report to the next meeting of the Council on its activities.

\section{Education Working Group}

The Council established an Education Working Group should be set up. It agreed that it should comprise the President, plus six members elected by the Council, including at least one member from each of the three categories - dentist, PCD and lay.

The Council agreed the following remit for the Group:

a) To consult stakeholders within and outside the dental educational institutions on the arrangements which the Council should establish to discharge its statutory duties for the regulation of dental education and

b)To report on those consultations to the next meeting of Council, with any recommendations it has been able to formulate in the time available.

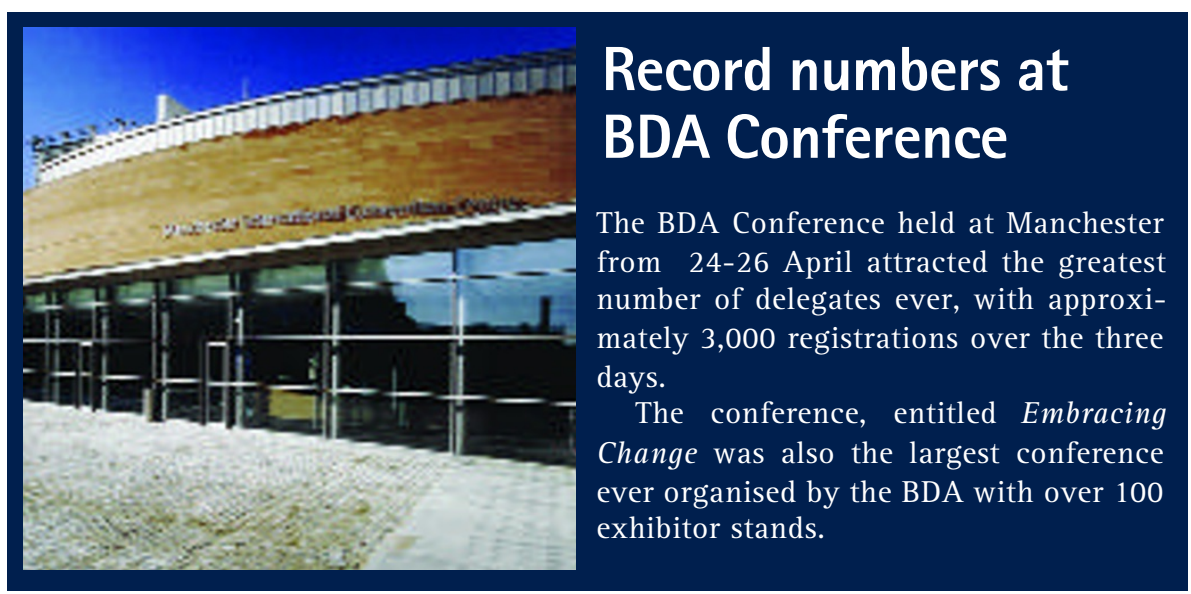




\section{BDA and Colgate team up to save faces}

The Facial Surgery Research Foundation Saving Faces will benefit from this year's Colgate Oral Health Month in association with the BDA.

The joint initiative was announced at the BDA conference in Manchester. The campaign will once again be in September and will feature road shows at six different shopping centres around the country.

The money raised for FSRF - Saving Faces will help fund a research nurse to identify new techniques for the early detection of mouth cancer.

FSRF - Saving Faces was launched in 2000 by Chris Smith, the Secretary of State for Culture, Media and Sport. The aim of the charity is to reduce the incidence of oral and facial disease and injury and to improve the outcome for people who suffer from them through research into their causes, prevention and treatment.

Mark Gilbert has been associated with Saving Faces from the outset, and his tender and unflinching portraits of faces before and after radical surgery have become the public image of the charity.

Dental professionals are invited to take part in Oral Health Month and support the initiative inpractice. The key message of the month is "Brush your teeth twice a day" and will be a slogan for the national coverage which is planned for TV, radio and print media.

For more information or to get involved, contact Colgate Direct on 01483401901.

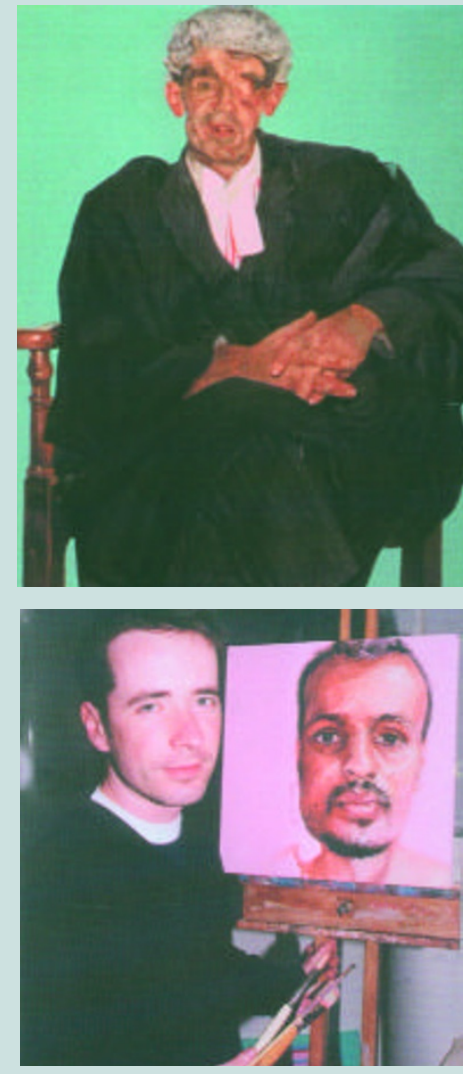

Mark Gilbert, pictured at work above, has been associated with Saving Faces from the outset. Mark's powerful portrait of Henry de Lotbinière (top) shows disfigurement is in no way a disablement.

\section{Help sought to find missing person}

The Bridlington Police Service requests the help of dentists who may have been in contact with Sybil Theresa Appelquist (Nee Hornby).

There is serious concern for Sybil's safety. She disappeared from her home in Bridlington in early/mid 2002. Her family is extremely worried and states that her disappearance is totally out of character.

Sybil was born on 15 August 1961 and had lived and worked within Bridlington all her life. Since she disappeared her husband has become unwell and has not been able to provide an explanation for her disappearance.

Sybil is described as a white female, 5 feet 4 inches tall. Her build has varied over the years but the most recent description was that she was of large build. She has dark collar length hair.

Sybil's dental records are unavailable but she has had extensive dental work, including two dental bridges on her upper front jaw, each bridge consists of three teeth and the centre tooth of each bridge is false and the surrounding teeth are fitted with crowns. The last dentist that Sybil was registered with was in Bridlington, East Yorkshire.

Anyone with information on the whereabouts of Sybil is urged to contact the police at Bridlington on 01262672222 or ring the National Missing Person Helpline on 0500700700 . All calls will be treated with the strictest confidentiality.

\section{Body identified}

An appeal by Northern Constabulary to establish the identity of a man whose body was found on the Isle of Skye in October 2001 (BDJ 193: 249) has proved successful.

The remains were identified as Christopher John Gray and formal identification was made from dental records. The Constabulary thanks $B D J$ readers for their assistance. 